\title{
Vanishing lung syndrome mistaken for bilateral spontaneous pneumothorax
}

\author{
Faisal A Khasawneh, ${ }^{1}$ Essam N Nakhla, ${ }^{2}$ Adnanul Karim, ${ }^{2}$ Ruba A Halloush ${ }^{3}$
}

${ }^{1}$ Section of Critical Care Medicine, Department of Internal Medicine, Texas Tech University Health Sciences Center, Amarillo, Texas, USA ${ }^{2}$ Department of Internal Medicine, Texas Tech University Health Sciences Center, Amarillo, Texas, USA ${ }^{3}$ Amarillo Pathology Group, Amarillo, USA

\section{Correspondence to} Dr Faisal A Khasawneh, faisal.khasawneh@ttuhsc.edu

\section{DESCRIPTION}

A 44-year-old male smoker presented with acute shortness of breath. The patient's vital signs were stable and his oxygen saturation was $87 \%$ at room air. A chest X-ray (CXR) showed bilateral apical hyperlucencies diagnosed as bilateral spontaneous pneumothorax (figure 1). He underwent bilateral16-French chest tubes placement. Follow-up CXR failed to show improvement (figure 2). A chest CT scan was performed and showed bilateral large bullae consistent with vanishing lung syndrome (VLS) (figure 3). The patient underwent a video-assisted thoracoscopy and bullectomy (figure 4).

VLS or giant bullous emphysema, is a progressive bullous disease characterised by large bullae that

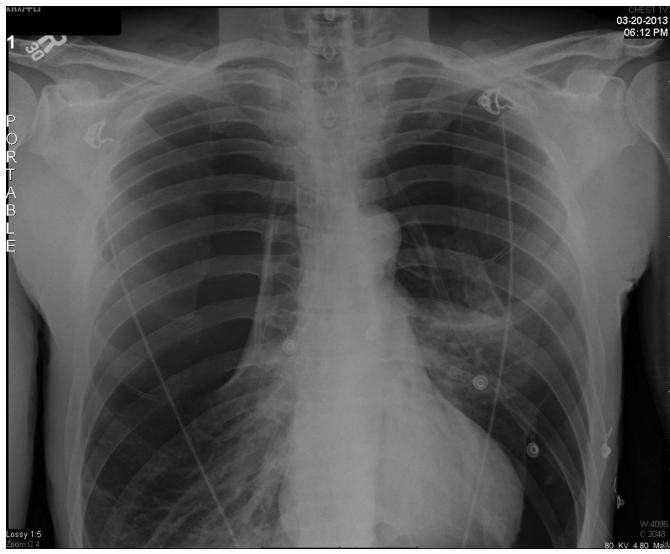

Figure 1 Close-up view of the admission chest X-ray showing bilateral apical hyperlucencies that were diagnosed as bilateral spontaneous pneumothorax. There is a smaller bulla in the left lower lung zone.

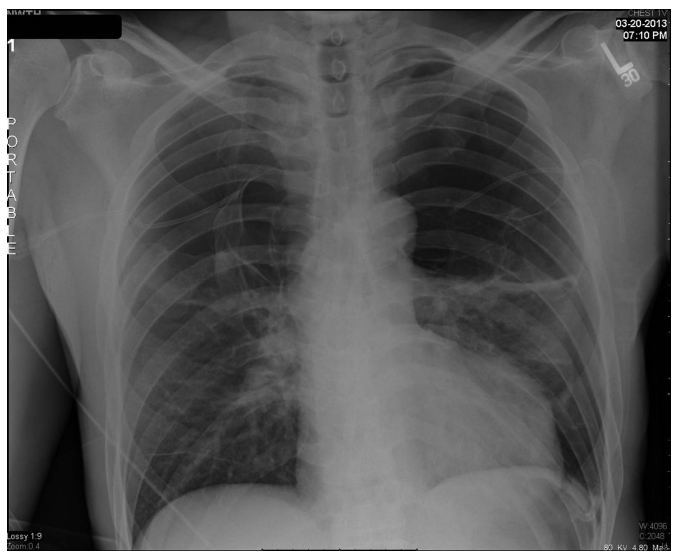

Figure 2 Follow-up chest X-ray showing bilateral chest tubes with no improvement in the apical hyperlucencies. involve at least one-third of one or both hemithorax. ${ }^{1}$ In VLS, paraseptal emphysema coalesces to form giant bullae. The formation of these intrathoracic spaces, and under influence of lung elastic recoil, causes healthy parenchyma to collapse rearranging itself to a lower expansion state. ${ }^{2}$
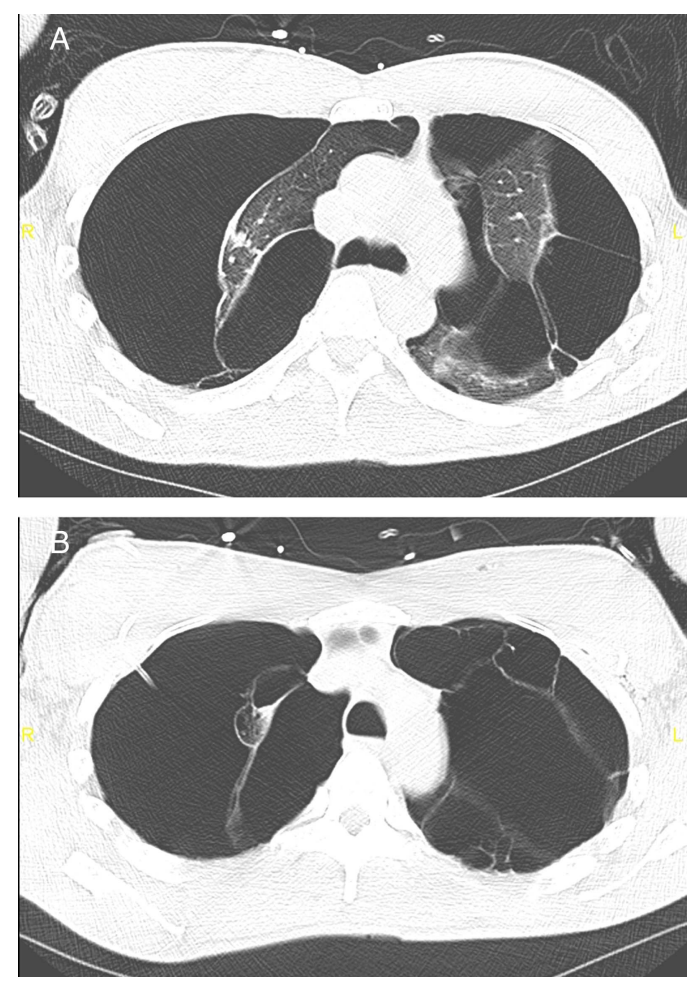

Figure 3 ( $A$ and $B$ ) Chest CT scan cross-sections showing bilateral large bullae with a chest tube located in a large right-sided apical bulla without evidence of pneumothorax.

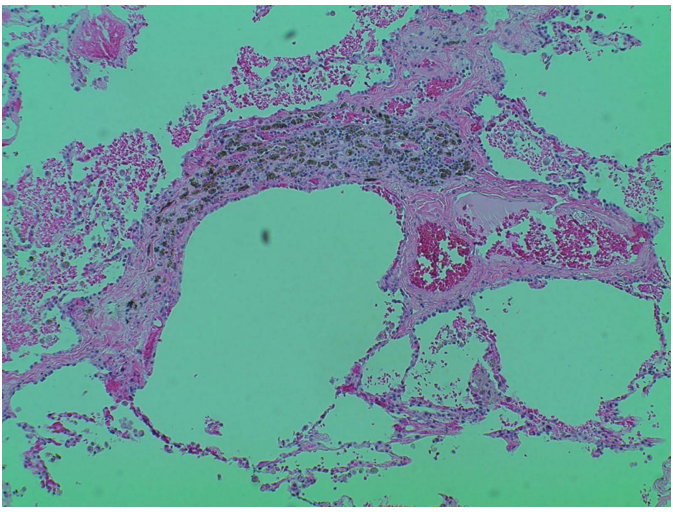

Figure $4 \quad H \& E-s t a i n e d ~ s e c t i o n$ from the resected lung tissue showing paraseptal emphysematous alveolar spaces (original magnification $\times 100$ ). 
This structural change is speculated to play a role in determining the size and progression of bullae. ${ }^{2}$ It usually occurs in young smoking men and tends to involve the upper lobes. Its progressive nature causes exercise intolerance, worsening dyspnoea and occasionally pneumothorax. The large size of bullae and its predominantly apical location makes it hard to differentiate from a

\section{Learning points}

- Vanishing lung syndrome (VLS) is a progressive bullous disease characterised by large bullae that involve at least one-third of one or both hemithorax.

- Pneumothorax is a potential complication in patients with VLS and large bullae and can be confirmed by identifying the 'double wall' sign; seeing the bulla wall separated from the chest wall by a rim of air.

- A chest CT can differentiate between pneumothorax and a large bulla, assess severity of the problem and provide helpful information to guide therapy. pneumothorax on CXR. ${ }^{1}$ The inability to see the entire lung pleural line separated from the chest wall on a CXR makes pneumothorax less likely and warrants further imaging. Bullectomy is the treatment of choice for VLS and interval followed up imaging is indicated because new giant bulla might develop again. ${ }^{3}$

Contributors FAK, ENN and AK diagnosed the case. RAH reviewed the pathology slides. All authors reviewed the literature and contributed equally in writing the manuscript.

Competing interests None.

Patient consent Obtained.

Provenance and peer review Not commissioned; externally peer reviewed.

\section{REFERENCES}

1 Lai CC, Huang $\mathrm{SH}, \mathrm{Wu} \mathrm{TT}$, et al. Vanishing lung syndrome mimicking pneumothorax. Postgrad Med J 2013;89:427-8.

2 Nazari S. Physiopathology of pulmonary emphysema. Analysis of structural changes in the pulmonary architecture and therapeutic implications. Minerva Chir 1998;54:261-75.

3 De Giacomo T, Venuta F, Rendina EA, et al. Video-assisted thoracoscopic treatment of giant bullae associated with emphysema. Eur J Cardiothorac Surg 1999;15: 753-6.

Copyright 2013 BMJ Publishing Group. All rights reserved. For permission to reuse any of this content visit http://group.bmj.com/group/rights-licensing/permissions.

BMJ Case Report Fellows may re-use this article for personal use and teaching without any further permission.

Become a Fellow of BMJ Case Reports today and you can:

- Submit as many cases as you like

- Enjoy fast sympathetic peer review and rapid publication of accepted articles

- Access all the published articles

- Re-use any of the published material for personal use and teaching without further permission

For information on Institutional Fellowships contact consortiasales@bmjgroup.com

Visit casereports.bmj.com for more articles like this and to become a Fellow 